\title{
Psychodynamic Understanding of Repetitive Self-Mutilation
}

\author{
Sumin Hong and Jee Hyun Ha \\ Department of Psychiatry, School of Medicine, Konkuk University, Seoul, Korea
}

반복적 자해의 정신역동적 이해

홍수민 · 하지현

건국대학교 의학전문대학원 정신건강의학교실

Repetitive self-mutilation or non-suicidal self-injury (NSSI) refers to the intentional destruction of one's own body tissue without suicidal intent and for purposes not socially sanctioned. Common examples include cutting, scratching, and hitting. Although NSSI generally has been considered a characteristic symptom of borderline personality disorder, its onset and prevalence typically occur in mid-adolescence, whereas the typical onset of borderline personality disorder is in early adulthood. Therefore, NSSI should be considered separately from borderline personality, but also from a psychodynamic perspective. From the classical psychoanalytic viewpoint, self-mutilation is associated with the failure to control aggressive drives. In ego psychology, self-mutilation is seen as an attempt of the fragile ego to re-establish boundaries with the external environment and avoid being overcome with uncontrollable emotions. In object-relation theory, it is seen as an effort to reconstruct unclear boundaries between ego and object or ego and reality by cutting the skin-the fundamental separation between them. Self-mutilation- can interfere with the psychotherapy by increasing or decreasing transference or causing strong countertransference. The therapist might experience helplessness or anger at repetitive self-mutilations and, with an adolescent patient, might be conflicted about telling the facts to parents or maintaining the patient's confidentiality. In conclusion, consideration of various psychodynamic aspects is important in understanding and treating patients with NSSI.

Psychoanalysis 2021;32(1):11-20

KEY WORDS: Self mutilation · Self-injurious behavior · Psychotherapy · Psychodynamic.

Received: August 26, 2020 Revised: December 1, 2020 Accepted: December 4, 2020

Address for correspondence: Jee Hyun $\mathrm{Ha}, \mathrm{MD}$

Department of Psychiatry, School of Medicine, Konkuk University, 120 Neungdong-ro, Gwangjin-gu, Seoul 05029, Korea

Tel: +82-2-2030-7569, Fax: +82-2-2030-7748, E-mail: jhnha@naver.com

\section{서 론}

반복적 자해는 자살 의도가 없이 자신의 신체 표면에 고 의적으로 출혈, 상처, 고통을 반복해서 유발하는 행동이다. 몇 년간 한국에서 반복적 자해를 하는 환자가 급격히 늘었다. 2014 2018년 사이의 보건복지부 통계에서 자해 및 자살시도 로 응급실을 내원한 환자의 변화를 보면 10대 73\% 증가, 20대 는 63.1\%가 증가하였다(Korea Suicide Prevention Center 2020). 통계에는 나오지 않으나 진료 현장에서는 10 대 초반 에서도 적지 않게 관찰된다. 지금까지 반복적 자해는 경계성 인격장애의 특징적 증상으로 간주해 왔다. 이들은 관심을 끌

This is an Open Access article distributed under the terms of the Creative Commons Attribution Non-Commercial License (https://creativecommons.org/licenses/by-nc/4.0) which permits unrestricted non-commercial use, distribution, and reproduction in any medium, provided the original work is properly cited.
거나 대인관계를 조정하기 위해, 취약한 자아 기능으로 발생 한 해리 현상을 중단시키기 위해서 등, 다양한 이유로 자해 를 한다. 그러나, 그 영향으로 인해 임상에서 자해 행동을 하 는 환자가 발생하면 경계성 인격장애로 먼저 진단하게 되는 편향이 있는 것이 현실이다. 그 결과 반복적 자해는 경계성 인격장애 진단을 위한 특징 증상(pathognomonic sing)으로 보는 시각이 생겼다. 경계성 인격장애는 전통적으로 치료하 기 까다롭고 어려운 환자로 분류되며, 예후가 좋지 않다. 또 자해뿐 아니라 취약한 자아 기능과 불안정한 대상 관계로 인해 정동의 불안정성, 충동성, 약물남용, 해리, 정신병적 증 상과 같이 다양한 다른 증상을 함께 갖고 있어 치료자로서 는 여러 가지 어려움을 예상하게 된다. 반복적 자해 행동을 하는 것으로 경계성 인격장애의 진단적 인상을 갖게 되면, 치료자는 환자의 치료가 매우 까다로울 것이고, 나쁜 예후를 가질 것이란 낙인효과에 의한 부정적인 예견을 할 가능성이 
높다. 무엇보다 10대 초반부터 ‘인격장애’로 진단할 연령대 가 아닌 시기인데도 자해 행동만으로 인격장애로 진단적 인 상을 갖는 것은 문제다.

그동안 임상 및 연구에서 경계성 인격장애의 다른 증상이 나 인격장애 특성 없이 반복적 자해만 하는 환자군이 관찰 되었다. 이들은 반복적 자해를 하는 것이 문제일 뿐, 인격장 애에 흔히 동반되는 문제는 없었다. 그리고 장기간 만성적 경과로 진행하는 경우가 많은 경계성 인격장애와 달리 짧게 는 수개월, 길게는 수년 이내에 문제가 해소되고 정상생활 범 주로 복귀하는 사례도 상당히 많았다(Wilkinson 2013). 이런 차이점이 부각되면서, DSM-5에서는 비자살적 자해(nonsuicidal self-injury, NSSI)라는 독립적 진단이 등재되었다. 이 진단 기준에서는 환자가 의도적으로 자신의 신체 표면에 직접 손상을 입히는 것은 맞지만, 그것이 자살을 의도한 것이 아니며, 문신이나 피어싱과 같이 사회적으로 용인되는 행동 은 배제하는 것으로 제한했다. 반복적 자해(repetitive selfmutilation)로 정의를 하는 경우도 이와 유사하나, 여기에 '전 반적 지적 손상'(general cognitive impairment)에 의한 것이 아닌 것이 포함된다(Favazza와 Rosenthal 1990). NSSI는 자 학, 자기부상(self-wounding), 자초한 폭력(self-inflicted violence), 자해, 의도적 자해(deliberate self-harm) 등 다양 한 이름으로 불린다.

이와 같이 반복된 자해를 경계성 인격장애와 분리하여 평 가하고 진단해야 할 필요가 더 많아졌다. 하지만 이 접근은 또 다른 문제를 만들었다. NSSI를 표현 정신병리(descriptive psychopathology)의 관점으로만 이해하고 목표 증상의 해소만 목표가 된 것이다. 행동을 표면적으로만 평가하고, 증상에 대한 평가를 횟수와 심각도의 측면에서만 보는 문제 가 생겼다. 자해 환자의 정동을 이해하고 복잡한 대인관계의 맥락과 자아 기능을 파악하는 것이 중요함에도 불구하고 오 히려 표면적으로 보려는 거리두기가 생긴 것이다.

이런 문제의식에서 저자들은 반복된 자해를 경계선 인격 장애의 개념적 이해를 벗어나 정신분석 및 역동적 측면에서 파악하는 것이 자해 행동의 본질을 파악할 수 있는 방법이라 고 생각했다. 자해는 한 가지 원인으로 설명하기 어려운 현상 이다. 생물학적 변인, 사회 및 환경적 영향, 심리적 측면에서 인지학습이나 정신역동, 사회심리적 관점 등 다양한 영역이 복잡하게 상호작용한 결과물이다. 자해를 다룰 때에는 중첩 된 다중적 요인과 복잡한 맥락에 대한 이해가 필수다(Suyemoto 1998). 그 중에서도 정신역동적 관점은 중요한 위치를 갖고 있다. 이런 생각을 바탕으로 하여 저자들은 반복적 자 해라는 정신병리를 정신역동적 관점에서 이해할 수 있는 여 러 관점을 포괄적으로 분석할 것이다. 반복적 자해를 하는
환자를 보다 더 광범위하게 평가하고, 문제의 심각성을 심도 있게 이해하고 파악하는 데 큰 역할을 할 것으로 기대한다. 마지막으로 반복적 자해를 하는 환자를 정신치료할 때 발생 할 수 있는 여러 문제를 제기하고, 치료를 할 때 고려해야할 사항들에 대한 임상적 제안을 할 것이다.

\section{반복적 자해의 증상학}

자해는 '의도적으로 자신의 신체에 상처를 입히는 행동'으 로, 넓은 의미에서 자살 시도의 목적은 없으나 지속적이고 의 도적으로 무모하게 스스로에게 상처를 입히는 행위다(Conterio 등 1998; Zila와 Kiselica 2001). 최근 여러 연구를 통해 자해를 자살과 구분하여 치료적 개입을 해야 한다는 의견이 제기되고 있으나(Lee 등 2016), 실제 임상에서는 자해가 자 살과 같이 자신의 몸에 해를 가하는 행위이고, 심할 경우 자 살에 이르기도 한다는 점에서 자해와 자살을 구분 없이 다 뤄왔다. 그러나 다수의 연구에서 자해와 자살에 차별적인 특 성이 존재한다고 보고하고 있으며, 자살 의도의 유무에 따라 비자살적 자해와 자살적 자해로 구분할 것을 제안하고 있다 (Lee 등 2016). 비자살적 자해는 자살 의도를 동반하지 않는 자해 행동이며, 자살적 자해는 자살 의도를 동반하는 자해 행 동이다. 광의의 자해는 문신, 피어싱과 같은 사회적으로 용인 되는 행위나 폭식, 약물남용과 같은 간접적 자기파괴적 행위 (self-mutilative behavior)까지 포함한다. 고전적으로는 자상 (cutting), 긁기(scratching), 때리기(hitting or banging), 파내 기(carving), 뜯어내기(scraping) 등이 있고, 자살 의도 없이 신 체 조직을 직접적으로 손상시키는 행위에 국한한다. 가장 흔 한 방법은 자상이다.

유발 요인으로는 성폭행, 헤어짐, 거절당함과 같은 부정적 이고 고통스러운 대인관계의 경험을 재경험하거나 직면하 는 상황에 시작하는 경우가 많다(Rao 2006). 그러나 일상의 스트레스도 촉발 요인이 될 수 있다. 가장 흔한 촉발 요인은 상실의 경험이다. 대부분 자해를 하기 전 강한 긴장, 불안, 분 노, 혹은 공포를 경험하고, 자해 후에 즉각적 안도를 경험하 거나 죄의식을 느낄 수 있다. 자해 후 긴장의 저하와 안도는 보상체계를 강화해 반복하게 만든다. 일부에서는 자해 행위 를 할 때 통증을 느끼지 않는다(Suyemoto 1998).

\section{역학과 경과}

반복적 자해의 유병률은 조사에 따라 다양한 분포로 보고 되고 있다. 이는 연구 방법에 따라 자해의 정의가 다르고 사 회 문화적 차이가 영향을 미친 것으로 추정한다. 평균 10 대 
중반에서 시작하여 20대 중반까지 지속되는 양상이 일반적 이다. 지역사회 청소년을 대상으로 한 연구에서 $14 \%$ 의 유병 률을 보고 했다(Ross와 Heath 2002). 지역사회 기반의 자해 를 메타 분석한 연구에서는 청소년에서 $17.2 \%$, 초기 성인기 $13.4 \%$, 성인기 $5.5 \%$ 로 보고된 것이 가장 신뢰할 만한 보고다 (Swannell 등 2014). DSM-5의 NSSI에 기반한 지역사회 청 소년 연구에서는 1.5 6.7\%가 관찰되었다(Kaess 등 2013). 호주에서 15 29세 사이의 1,943명을 대상으로 장기간 추적 한 연구가 있다. 반복적 자해는 15 16세를 전후한 시기에 가 장 높았고 20대 초반이 되면서 줄어드는 양상이었다. 이 중 반 복적 자해는 $8 \%$ 정도였고, 여성이 남성보다 많았으며(10\% vs. $6 \%$ ), 평균 수년간 지속되었다. 공존 문제로는 우울, 불안, 반 사회적 행동, 알코올, 대마초 등이 있고, 성인기에는 우울 및 불안이 뚜렷하게 연관되어 있었다(Moran 등 2012). 정신과 치료 중인 임상군을 대상으로는 유병률이 높았다. 1 년 안에 자해를 한 청소년이 $46.5 \%$ 였고, 이 중 $60 \%$ 는 중등도 이상 위 험한 수준의 반복적 자해를 하였다. 평균 12.9회를 하였고, 평 균 2.4가지 방식을 이용하였다. 입원 중인 청소년을 대상으 로 한 연구에서는 60 80\%에서 자해를 보고하기도 했다. 여 성이 많고, 일찍 시작하고, 방법으로 자상(cutting)을 많이 했 다(Lloyd-Richardson 등 2007).

한국에서는 2017년과 2018년에 교육부가 중고생 96만 명 을 대상으로 학생정서행동 특성 검사를 시행하면서 자해 유 무를 조사하였다. 자가보고검사로 이뤄진 한계가 있으나 2018년 중학생은 “자해를 한 적이 있나”라는 질문에 “조금 그렇다" 이상의 대답을 한 경우는 $7.9 \%$, 고등학생은 $6.4 \%$ 였 다(Hankyoreh 2018). 2018년 경기도 초중고 정서 및 행동 특 성 검사 전수조사에서 대상자 48 만 명 중 자살 사고를 보인 비율은 3\% 정도였다(Gyeonggi Office of Education 2018). 이는 자가보고 검사의 과소 보고 성향을 고려하면 꽤 높은 수준으로 추정한다. 응급실 방문자나 응급 진료망에 보고된 수를 집계한 통계는 임상군을 추정할 수 있는 자료다. 2016 년 중앙응급의료센터 통계에 따르면 매년 2,200명 정도로 전 연령 대비 약 8.3\% 정도였다(National Emergency Medical Center 등 2017). 한국 자료에서 자해의 동기로는 정신적 어 려움이 가장 컸으며, 학교 성적과 가족 간 갈등, 선후배 또래 갈등이 열거되었다(Korea Suicide Prevention Center 2020).

\section{비정신역동적 관점}

정신역동적 관점과 생물학적 요인을 배제한 다양한 측면 에서도 반복적 자해를 설명할 수 있다. 먼저 미디어의 영향 이다. Ministry of Health and Welfare(2018)의 조사에 따르
면, 자살 유해 정보의 77\%가 SNS를 통해 알려지고 있다고 한 다. 특히 SNS에 유해 사진이나 정보를 유포하여 신고가 접수 된 사건의 $84 \%$ 가 자해 관련 내용인 것으로 나타났다. SNS의 사용 증가는 청소년들의 무분별한 모방 행동의 증가와 관련 이 있다는 점(Kwon 2016)을 고려해 보면, 특히 청소년의 반 복적 자해의 증가와 감소는 미디어에서 노출되는 자해가 영 향을 강하게 미칠 수 있다고 본다.

사회심리학적으로는 Bandura의 모델링(modelling) 이론 을 적용해 보았다(Suyemoto 1998). 자해 행동은 사회적 환 경과 개인 사이의 상호작용에 의해 형성된다고 할 수 있다. 만일 가족 안에서 일상적인 학대가 있거나 구성원 중 자해 를 하는 사람이 있다면, 그 환경에서 생활한 사람에게는 자 해가 의미를 갖게 되고 나름의 상황 대처의 기능을 갖는다. 그런 면에서 순기능이 있고, 자해 이후 고통을 경험한다는 것은 주변의 돌봄을 받을 이유도 된다. 일련의 과정은 사슬 과 같이 연결되어 반복적으로 재생되며 자동으로 강화된다. 이런 과정 안에서 자해는 모델링, 학습을 거쳐 강화되는 것으 로 설명할 수 있다. 대인관계와 환경과의 관계에 있어 타인의 관심과 염려를 구하려는 관심 끌기는 자해 행동의 강한 강화 요인이다. 특히 자아의 발달이 미숙한 10 대 청소년의 경우 또 래 집단에서 자기 위치를 분명히 하는 게 매우 중요하다. 이 때 자해는 집단 안에서 자기 위치를 확보하기 위한 행동의 하 나가 된다. 만일 자신을 드러내는 표현이자 집단 안에서 자신 만의 정체성의 한 부분이 된다면 그 행동은 강화된다. 이로써 강한 2차 이득을 얻게 되고, 타인을 조종하는 기능도 한다. 한 연구에 따르면, 일부 환자들 사이에서는 자해 행동을 얼마나 자주 그리고 심한 정도로 하는지 집단 내 경쟁 양상이 관찰되 기도 하였다(Simpson 1980). 한국 10대들 사이에서 SNS상에 자해 관련 해시 태그를 붙이는 것이 유행한 것은 일종의 집단 내 경쟁의 양상이었다. 개인이 생활하는 가족이나 사회가 역 기능적으로 작동하고 있다면, 자해 행동은 거꾸로 자신의 항 상성이나 역기능적 환경에서 균형을 유지하는 데 나름의 기 능을 한 것으로 해석할 수있다(Allen 1995).

자해 행동을 폭식증이나 발모광과 유사한 행위 중독의 관 점에서 바라보는 관점이 있다. 처음에는 손목에 작은 흠집을 내는 것에서 시작하지만, 점차 빈도가 잦아지고 방법 또한 더 위험한 방향으로 발전해나가는 것이 흔한데 이를 '내성' 으로 해석할 수 있다. 자해를 하지 않은 채 일정한 시간이 지 나면 공허하고, 불안해지며, 긴장이 견디기 어려운 수준으로 올라간다. 다른 행위로는 이 불편감이 해소되지 않고 오직 자해 행위로만 해결이 되기도 하는데, 이는 '금단'과 유사하 다. 자해 행위를 편하게 할 수 있는 공간을 찾고, 자해를 할 이유를 찾는 데 많은 시간을 보내는 것과 같은 행동은 중독 
의 특징적 구갈(craving)이다. 이와 같이 반복적 자해가 발생 하고, 그 행위가 삶과 생각의 중심에 선다면 중독 개념으로 해석할 여지가 충분하다.

\section{정신역동적 이해}

\section{고전적 정신분석}

고전적 정신분석 관점에서는 공격적 욕동(aggressive drive)이나 성적인 욕동(libidinal drive)을 중심으로 자해를 이해한다. 자해를 하는 사람은 기질적으로 강한 공격적 욕동 을 갖고 있다. 그런데 환경에서 어떤 이유로 욕동의 조절을 실패하면서 정동의 불안정이나 충동의 조절 어려움으로 자 해가 일어난다(Kernberg 1984). 일차 과정(primary process) 이 억압되지 못한 채 의식으로 표출되면서 강하고 조절되지 않는 공격적 감정이 일시적으로 분출되며 자해하는 것이다. 자기 파괴적 행동의 측면에서 자해는 죽음 본능인 타나토스 와 직접 관련이 있다고 볼 수 있다. 다른 관점으로 완벽한 자 기 파괴가 일어나는 것을 피하기 위한 리비도와 타나토스 사 이의 타협 형성의 일환으로 자해를 해석하기도 한다(Firestone과 Seiden 1990). 자아의 타협 형성이란 측면을 강조한 해석이나, 역시 기본적으로 타나토스가 매우 강한 욕동으로 작동하고 있다는 점에서는 고전적 정신분석 관점에서 언급 할 부분이라고 파악하였다. 공격적 욕동을 투사 검사로 평가 한 연구가 있다. 이 연구에서는 경계성 인격장애 환자들을 자해를 반복적으로 하는 군과 그렇지 않은 군으로 나눈 후 로르샤흐 검사를 시행하였는데, 자해 환자군에서 일차 과정 에 준하는 공격성으로 평가할 만한 지표가 더 많이 관찰되 었다(Fowler와 Hilsenroth 1999). 이 역시 자해가 원초적 공 격 욕동(primary aggressive drive)과 깊은 관련이 있고, 제 대로 통제되지 않을 때 실현된다는 것을 지지하는 증거다.

리비도의 관점에서는 자해 행동을 성적인 만족이나 감정 을 느끼는 것을 피하려는 노력으로 보거나, 용납하기 힘든 성적인 감정이 드는 것에 강한 벌을 주려는 시도로 해석한 다. 사춘기 2 차 성징 이전에는 자해 행동이 매우 드물다는 점에 착안한 해석이 있는데, 청소년기에 오이디푸스 콤플렉 스가 재현되면서 그로 인해 붕괴나 압도가 일어나는 것을 막기 위한 방어나 노력의 일종으로 해석할 여지는 있지만 제한적이라 생각한다. 일부 환자에서는 자위와 같은 성적인 만족, 자신의 몸에 대한 통제력을 성적인 측면에서 이해하는 것, 가학-피학적 측면으로 보는 것이 가장 적합한 사례가 있 을 것이다. 초자아의 발달이 미흡하거나 가혹한 경우에는 자 연스러운 청소년기의 리비도 증가를 수치스럽게 느끼거나, 몸을 처벌의 대상으로 인식해 자해를 할 가능성이 있다. 가
학-피학적 성향이 있는 경우, 사춘기 이후 그 영역이 성화 (sexualize)되며 자해를 할 수 있다는 사례 보고가 있다. 정 신역동적 관점에서 의존과 독립, 조종과 힘의 균형 사이의 문제가 피학적 측면에 의해 부각되어 고통스럽고 불쾌한 자 해 행위로 이어진 것이다(Asch 1988).

\section{자아심리학}

자아심리학에서 자해는 취약한 자아 기능의 결과다. 외부 와 소통 및 경계 짓기에 혼란이 있고, 솟아오르는 욕동을 충 분히 제어하지 못했기 때문이다. 자아를 중심으로 무의식적 욕동의 증가 및 현실과 관계에서 혼란이 발생한다. 자아가 이를 조정하지 못할 때 주도권을 되찾으려는 노력의 일환으 로 자해를 하게 된다. 이는 경계성 인격장애가 아니라도 다양 한 정신병리나 심한 인격장애에서 일반적으로 발생 가능하 다. 자아가 충분히 그 기능을 하지 못하면 공허감, 조각 날 것 같은 두려움, 비현실감, 해리를 경험한다. 그 반응으로 자아 와 외부 환경 사이의 경계를 뚜렷하게 재확립하려는 노력을 하는데, 그중 하나가 자해다. 취약한 자아를 가진 개인은 또 렷하게 눈에 보이는 상처를 내어 이를 확인하고, 강한 고통 을 느끼는 것으로 생존을 확인한다. 시각적으로 피가 흐르는 것을 보며 비로소 해리 상태에서 벗어날 수 있고, 흐트러졌 던 자아와 현실 사이의 경계가 재정립된다. 그런 면에서 자 해는 정신적인 응급상황에 대처하는 기능을 한다.

자아의 측면에서 정서의 조절로 자해가 기능한다. 감당할 수 없는 정서적 파도가 엄습하면, 자칫 자기를 잃어버릴지 모른다는 위험을 느낀다. 강한 감정의 파도가 세상과 자아의 연결을 단번에 끊어 버리고, 이를 만회할 길이 없어질 지 모 른다는 절멸 공포(fear of annihilation)를 느낀다. 자아는 거 대한 정서의 흐름을 끊거나 방향을 바꾸는 일을 자해가 해 줄 것을 기대한다. 그 결과 통제력을 영구히 잃는 것을 막을 수 있을 것이라 믿는다. 결국 자아의 관점에서 자해는 참을 수 없게 엄습하는 정서를 표현하고 외현화하는 행위의 하나다 (Himber 1994).

이와 같이 자아심리학적 관점에서는 비록 자해가 자기 파 괴적이고 해로운 행동이지만, 통제할 수 없는 정서적 고통에 무차별적으로 압도당할지 모른다는 두려움을 신체적 고통으 로 전환하여 조절하려는 타협적 노력이다(Raine 1982). 자해 는 정서적 고통이 매우 깊을 때 워낙 강렬하고 이해하기 힘 들기 때문에 차라리 신체적 고통을 느끼는 게 낫다고 선택하 는 자아의 입장의 타협 행위다(Leibenluft 등 1987).

Kernberg(1984)는 악성 자기애(malignant narcissism) 성 격을 가진 환자에서 자해를 설명했다. 이들의 자해는 특이하 다. 일반적으로 자기애적 성향은 일상생활에서 타인에게 큰 
관심이 없고 거리를 둔다. 그러던 중 과대한 자기 이미지가 손상될 위기에 처하면 극심한 수치심을 느낀다. 악성 자기애 환자는 수치심을 없애기 위해 몸에 물리적 손상을 가한다. 이 행위는 자신의 내면 세계에 대한 무의식적 승리의 의미로 인식된다. 보통 자기애가 강한 경우 몸을 훼손하는 행위는 하지 않는다. 악성 자기애 구조를 가진 경우에는 자기애적 분노와 수치심이 워낙 강렬해 자해 행위만이 그 감정을 억누 를 수 있기에 그 행동을 하는 것이다. 악성 자기애 인격장애 환자에서 자해에 대한 병리를 Kernberg(1984)의 경계성 인 격구조(borderline personality organization)의 개념적 특성 중 방어기제의 측면에서 이해해 볼 수 있다. 이때 자해는 원 초적 방어인 분리(splitting), 이상화(idealization), 평가절하 (devaluation)의 결과로 해석할 수 있다.

\section{대상관계이론}

대상관계이론에서는 대상 항상성 획득의 실패와 불안정한 내적 자기-대상 표상으로 인해 자신과 외부 사이 '경계(boundary)'가 모호해지는 현상으로 자해를 설명한다. 반복적인 자해 청소년 환자를 치료했던 정신분석가 Doctors(1981)는 대상 항상성(object constancy)을 획득하지 못한 것이 자해의 핵 심 병리라고 주장하였다. 경계성 인격 형성 과정의 측면에서 보면 타당한 설명이다. 어린아이는 생애 초기 여러 가지 경험 의 좋고 나쁜 측면을 처리하고 조절하려는 노력을 통해 내 적 세계를 발달시킨다. 이 과정에서 부모로부터 지지적인 보 살핌을 받고 과도한 좌절이 없다면 좋은 자기-대상 표상과 나쁜 자기-대상 표상을 통합하여 안정적인 자기-대상 표상 을 형성하게 된다. 성공적으로 대상 항상성을 획득한 개인은 좌절스러운 상황에서도 좋은 자기-대상을 유지할 수 있게 된 다. 그러나 부모로부터 감정적 공감의 결여, 신체 및 정서적 방임과 학대 등을 경험하게 되면 좋고 나쁨의 모순된 감정을 통합하지 못하게 되고, 나쁜 경험을 처리하고자 분열과 투사 적 동일시에 의지하게 된다. 이는 멜라니 클라인이 애기했던 편집 자리(paranoid-position)의 상태에 고착된 것으로 볼 수 있다. 편집 자리에서 개인은 나쁜 대상으로부터 파괴당할 수 있다는 위협을 느끼며 박해 불안(persecutory anxiety)을 느낀 다(Klein 1932). 이렇듯 취약한 내적 자기-대상 표상을 가지 고 자란 사람은 스트레스 상황에서 쉽게 경계 붕괴의 위험 을 느낀다. 개인은 조각조각 부서지는 느낌, 공허함, 비현실 감, 내면의 죽음과 같은 공포스러운 감정을 경험한다. 자해 행동은 이러한 상태에서 벗어나고 경계를 확보하려는 노력 의 결과다. 자해 행위를 통해 자신의 몸과 현실세계 사이의 경계를 다시 정립하고, 자아와 몸의 실체를 확인하는 일을 반복한다.
경계를 생각할 때 자해와 가장 밀접한 연관된 기관은 '피 부’다. 피부는 존재를 눈으로 확인하며 자신과 타인, 자신과 대상 사이의 경계를 분명히 하는 원초적이고 즉물적인 경계 다. 경계의 관점에서 피부는 매우 중요하다. 피부를 경계로 안쪽은 나(me)를, 그 밖은 내가 아닌(not-me) 구역으로 확실 히 구별할 수 있다. 정신세계에서 나와 '내가 아닌' 사이의 경 계가 불분명해질 때 피와 상처, 고통은 경계를 재정립해준 다. 자해를 통해 자아 표상과 대상 표상 사이의 불분명한 경 계로 인한 혼란을 잠시나마 없앨 수 있다. 그러나 경계가 모 호한 상태가 오래 지속되어왔기 때문에, 자해로 인한 경계 다시 짓기는 그다지 오래 지속되지 못하기에 대부분의 자해 를 반복하게 된다.

정신치료 과정에서 자해를 하는 환자는 자신의 대상 관계 가 그렇듯이, 치료자와의 대상 관계가 안정적이지 않다. 치 료자를 포함한 중요한 인물을 조종하려는 노력의 일환으로 환자는 분노, 무력감, 억울함 등의 강한 감정을 경험하며 자 해를 통해 긴장을 줄이려 한다(Kernberg 1984). 자해로 자기 와 타인 사이의 희미한 연결성과 경계를 확인하려 하지만, 반복적 자해는 오히려 불안정성을 강화시키는 역효과를 일 으킨다.

대인관계에서 타인으로부터 거절은 강한 분노 반응을 일 으킨다. 분노는 처음에는 당사자인 타인을 향하나, 이후에는 관계 자체 혹은 자신의 대상 표상과의 상호관계에서 그 대상 을 파괴할 수 있다는 공포로 전환되어 분노는 자신을 향한다 (Suyemoto 1998). 우울증을 자신을 향한 공격성으로 해석하 는 정신 역동과 유사한 패턴이다. 자기 혐오는 부정적인 자기 상의 내재화로 인한 대상 관계의 발달과 관련 있다. 내재적 나쁨, 틀림, 더러움, 고통의 감각과 어머니의 공감 실패가 공 존할 때, 자해가 발생할 가능성이 있다. 부정적인 자기 표상 이 지속되면 자기 처벌이 합리화되며, 자신을 파괴하는 것이 낫다는 믿음으로 나아간다(Noshpitz 1994). 이와 같이 대상 관계이론은 고전적 정신분석이론에 비해 정신발달, 대인관 계, 치료적 관계 측면 모두에서 유용한 실마리를 준다.

\section{자기심리학}

자기심리학적으로 자기의 구조적 응집력(structural cohesion)과 긍정적 정서의 감각을 유지하기 위해 자기 파괴적 행위인 피학적 행동이 무의식적으로 일어날 수 있다고 해석 한다. 자기심리학은 자신의 정신을 응집력 있는 전체, 즉 자 기로 조직하려는 개인의 욕구를 인간 심리의 가장 근본적인 동기로 본다. 여기서 구조적 응집력이란, 스스로의 정서 상태 를 안정된 상태로 유지할 수 있으며, 따라서 자기 파편화의 위협을 느끼지 않는 상태를 말한다(Kohut 1971). 인간은 생 
애 최초의 시기에 파편화된 자기로서 존재하다가, 헌신적이 고 공감적인 어머니의 보살핌을 받으면서 차츰 응집력 있는 자기로 발달한다. 이러한 과정에서 개인은 자기애적 욕구가 충족되며 스스로를 자신 있고 가치 있는 존재로 경험한다. 이 런 경험을 통해 응집력을 획득하게 된다. 응집적 자기(cohesive-self)를 확립한 개인은 계속해서 반응해주고 공감해 줘 야 하는 대상의 필요성으로부터 벗어나 자기애적 상처를 어 느 정도 스스로 치유할 수 있는 건강한 자기를 유지할 수 있 다. 그러나 자기애의 상처에 취약한 사람은 자해와 같은 자기 를 향한 원초적 공격성의 표현을 한다. 관계를 마음대로 조정 하지 못하는 것과 같은 일이나 미러링의 실패는 자기애적 인 격장애 환자의 구조적 결핍을 자극하고, 자해로 이어진다 (Stolorow와 Lachamann 1980).

\section{정신발달적 측면}

청소년기에서 초기 성인기는 반복적 자해가 빈번한 시기 이므로 정신발달적 측면에서 살펴볼 필요가 크다. 아이는 적 절한 환경 안에서 보살핌을 받으며 '절대적 의존'에서 '상대 적 독립'으로 발달한다. Winnicott은 정신증을 설명하면서, 아이가 발달 과정에서 적절한 양육 환경이 제공되지 않았을 때 경험했던 붕괴의 경험을 다시 경험할까봐 느끼는 극심한 공포를 '원초적 고통(primitive agony)'이라 했다. 이는 초기 의 원초적 상태로 되돌아가 버릴지도 모른다는 상상이상의 강렬한 경험이라고 Winnicott은 설명했다(Winnicott 1945). 원초적 고통을 경험하게 되면, 자신이 조각나거나 붕괴되어 자아의 응집력을 잃어버릴 것이라는 두려움이 커진다. 이때 무엇이라도 하려고 하는데 그 중 하나가 자해다. 그렇게 해 서라도 원초적 고통을 경험하지 않는 상태로 되돌리고 싶어 할만큼 간절한 것이다. 발달 과정에 어떤 어려움으로 인해 원초적 고통을 경험할 정도로 자아가 쉽게 퇴행을 하는 경 우 자해는 반복될 수 있다.

다음으로 언어와 상징화 발달의 부재가 자해와 연관될 수 있다. 언어화(verbalize)하는 능력의 발달이 제대로 이루어 지지 않은 것이 자해 행동으로 이어진다. 상징화를 적절히 할 수 없고, 이를 언어로 표현하지 못하면 갈등이나 감정을 조절하는 데 큰 어려움을 경험하게 된다. 발달 과정에서 감 정 상태를 점차 세분화하여 인식하고, 이를 적절히 상징화하 여 언어로 표현하는 능력을 획득한다. 이 과정을 잘 이루지 못한 경우 언어로 감정을 조절하거나, 또는 강렬한 감정으로 부터 거리를 두는 것을 제대로 하지 못한다. 더욱이 심상에 서 어떤 감정이나 생각을 상징화하는 것을 잘 하지 못하면 감정 상태를 인식하고, 나아가 언어로 표현하지 못한다. 특 히 10 대 이후 대인관계가 언어로 주로 이루어지기 시작하
고, 감정 표현이 다채로워지는 시기가 되면 더욱 이 능력의 미숙함이나 결핍은 부정적인 영향을 강하게 미치게 된다. 그 결과 언어 대신 즉각적인 신체 행동인 자해 행동을 하는 것으 로 전환되는 것이다(Sarnoff 1988; Suyemoto 1998). 문제는 이 행동으로 감정 상태를 이해할 수 있게 되거나, 자신의 감 정을 적절하고 세분화해서 타인에게 전달할 수 있는 게 아니 라는 것이다. 결국 감정이 격해질 때마다 자해를 하게 되고, 언어화했다면 받을 수 있었던 피드백이나 정서적 조율, 공감 적 반응을 얻지 못하기에 자해를 반복하는 악순환에 빠진다.

다음은 청소년기의 발달심리적 측면이다. 이 시기는 정체 성 형성을 위해 부모와 자신 사이를 분리하고 독립하는 2 차 분리-개별화 과정이 필요하다. 소아기에 안정적 애착 형성 이 이루어지지 않아 불안정한 대상 관계를 가진 청소년은 분 리-개별화 과정에서 자아와 대상 사이, 자아와 부모상 사이, 자아와 외부 환경 사이의 경계가 불분명하게 느낀다. 청소년 기에 만나는 2 차 분리-개별화 과제로 인해 불분명함은 강렬 한 불안과 혼란으로 발전한다. 그 불안과 공포를 통제하고 경계를 재설정하려는 노력의 일환으로써 자해를 하는 것이 다. 저자들은 자해가 대부분 청소년기에 처음 시작되는 것이 이러한 2 차 분리-개별화 과정에서 경험하게 되는 불가피한 불안과 연관되는 것이라고 생각한다.

나아가 자해로 생기는 상처와 흥터는 자신의 정체성을 의 미하는 하나의 도구가 되기도 한다(Raine 1982). SNS에 청 소년들이 자해 후에 '\#자해'와 같은 해시 태그를 붙여 사진 을 공유하는 것이 유행처럼 번지는 현상인 것도 같은 맥락 이다. 자해로 집단 정체성을 공유하며 그 시기에 특징적으로 경험하는 고립감을 줄이고, 정체성을 확인하려는 과정이다. 만일 자해를 반복하다가 문신이나 피어싱으로 넘어간다면, 이는 청소년기 발달 과정의 자연스러운 사회화나 승화, 타협 형성으로 해석할 부분이 많다.

청소년의 자해 행동은 정상적 청소년기 자기애의 왜곡된 표현의 하나로 자기애적 분노(narcissistic rage)의 표현이다. 사춘기 청소년은 자아상을 재구성하는 과정에서 내적 고갈 과 공허함을 많이 느낀다. 이 공허함을 특이한 방식으로 방 어하는데, 전능감(omnipotence), 독창성(uniqueness), 불멸 감(invulnerability 또는 indestructibility) 등을 이용한다. 내 부와 외부에서 오는 스트레스, 대인관계에서의 상처, 환경에 서 좌절을 경험할 때 이 전능감과 불멸감에 대한 의문이 발 생한다. 여기에 자기애적 분노가 함께하는 경우, 전능과 불 멸감을 확인하고 싶은 욕구와 만나 자해 행동을 할 수 있다. 자해를 해도 상처받거나 부서지지 않는다는 것을 직접 확인 해보고 싶은 것이다. 강한 통증과 공격성을 표현으로 일시적 으로 자기애적 분노가 가라앉고 동시에 죽지 않고, 망가지지 
않았음을 확인하면서 안도한다. 이 두 가지 기능은 전능감을 포함한 자기애적 만족을 주기에 충분하다. 다만 건강한 자아 나 자기애가 선택할 방법이 아니라는 것이 문제다. 그러나, 자해가 위험하고 금지된 행동이면서 남들이 흔히 하는 행동 이 아니라는 것은 청소년의 독창성을 만족시키는 기능을 한 다. 이런 면들이 복잡하게 상호작용을 하면서 반복적 자해를 하는 것은 청소년기의 미숙한 자기애와 연관되어 있다.

청소년기의 또 다른 발달적 측면에서의 특징은 사회 전염 (social contagion) 현상이다. 이는 집단 행동을 병이 전염되 어 퍼져나가는 현상에 비유한 것인데, 사람들의 정서와 행동 이 한 사람에서 다른 사람에게로 옮겨지는 것을 의미한다. 실제로 청소년에서 첫 자해 경험은 또래집단의 영향을 크게 받는다. 자해하는 청소년 주위에 자해하는 친구들이 있는 경 우가 많은 것을 통해 이를 알 수 있다.

\section{정신치료적 고려}

반복적인 자해 환자와 정신치료를 시작할 때, 혹은 치료 과정에 처음으로 자해를 하는 상황이 발생하면, 치료자는 정 신치료 세팅과 진행뿐 아니라 현실적인 측면에서 다양하고 신중한 고민을 하고, 중요한 결정을 내려야 한다. 정신치료 를 하기 전 예비 면담을 할 때 자해 경험이 있는 것을 알게 되면, 치료자는 약한 자아 기능, 대상 관계의 불안정성, 높은 충동성, 치료 세팅을 유지하는 것이 앞으로 어려울 수 있다 는 점 등 여러 가지 면을 예상하는 단서로 여긴다. 정신역동 적 정신치료의 치료 세팅에 반복적 자해 경험은 치료 세팅에 서 치료 횟수, 정신역동적 치료의 수준, 치료자의 개입의 정 도 등에 대한 계획을 세울 때 고려할 중요한 요소의 하나다.

일반적으로 반복적 자해는 변증법적 행동치료나 인지행 동치료를 우선적 적응증으로 본다. 그러나 지금까지 고찰한 것을 보면 많은 환자에서 정신역동적 측면이 중요하게 작동 한다. 그러므로 정신분석, 혹은 정신분석적 정신치료가 더 치료적으로 적합한 사례도 적지 않을 매우 많을 것이다. 그러 므로 정신분석, 혹은 정신분석적 정신치료가 치료적으로 더 적합한 사례도 적지 않을 것이다. 최근 정신역동적 정신치료 가 다양한 범위의 자해를 동반한 정신 질환의 치료에 있어 인지행동치료만큼 효과적이라는 것을 보여주는 경험적 증 거가 있다(Shedler 2010; Driessen 등 2013; Yakeley 2014). 또한 자살 시도와 자살 성공률이 매우 높은 치료 저항성 우 울증 환자에 있어서 정신역동적 정신치료의 효과가 있다는 연구보고도 있다(Fonagy 2015).

반복적 자해를 하는 환자에게 정신분석적 정신치료를 할 때 이런 점을 고려해야 한다. 먼저 자해는 해서는 안 되는 행
동이지만, 순기능적 효과를 갖는 것도 분명하다. 치료자는 자해의 순기능적 측면으로 인해 내적 보상이 있고, 이로 인 해 반복되고, 행동이 강화되는 순환기전이 있음을 알고 있어 야 한다. 자해는 즉각적으로 감정적 고통을 완화해 주는 기 능을 한다. 이로써 환자의 심한 감정적 고통이 신체적인 통 증으로 전환되어 잠시나마 잊을 수 있게 된다. 그리고 높아 진 내적 긴장감을 순간적으로 완화하며, 불안으로부터 벗어 날 수 있는 만족감을 제공한다. 사례에 따라서는 의식적으로 쾌감을 느끼고자 자해를 하기도 한다. 대인관계나 가족 내에 서 관심과 걱정과 같은 이차 이득(secondary gain)을 얻기 위 해 자해를 하기도 한다. 나아가 자해는 신체를 통제하는 전 능감을 느끼게 하고 살아있음을 경험하게 한다. 이렇게 치료 자는 환자가 경험할 수 있는 자해의 여러 가지 기능적 효과 를 섬세하게 이해하여, 궁극적으로는 서서히 다른 방법으로 대체하거나 다른 심리 기제로 전환하도록 도와야 한다. 이것 이 반복적 자해를 하는 환자의 정신치료의 요체다.

치료를 하는 과정에서 자해는 치료자와 환자 양측에 영향 이 있다. 자해를 견디는 과정에서 치료자는 불가피하게 역전 이적 난관(countertransference impasse)에 봉착한다. 환자가 전이적 관점에서 표현하는 분노를 치료자가 안고 가는 것은 쉬운 일이 아니다. 치료 중에 치료자는 견디기 힘든 수준의 불편한 감정을 느끼거나, 좌절한 환자를 지나치게 감상적으 로 대하는 반응을 할 수 있다(Fowler와 Hilsenroth 1999). 어 떤 치료자는 자해를 반복하는 환자를 직접 달래는 태도를 취 하면서 무의식적으로 조종하고 안정시키려 하거나, 환자의 투사적 동일시의 대상이 된다. 모두 치료의 중립성과 온전한 치료 과정을 훼손할 위험이 있다.

한편 전이는 자해의 증가와 감소에 영향을 미친다. 긍정적 전이의 일환으로 잘 보이기 위해 그동안 반복하던 자해를 잠시 멈출 수 있다. 치료자는 이 변화에 안도감을 느끼고 환 자가 호전되었다고 생각할 수 있지만, 또 다른 문제들로 다 르게 표현되기도 한다. 예를 들어 자해를 하는 대신 술을 많 이 마시거나 처방받은 약을 한꺼번에 치명적이지 않을 정도 로 복용할 수 있다. 무의식 중에 자기 파괴적인 대인관계를 하기도 한다. 이러한 현상은 직접적인 자해 행동이 광범위한 맥락의 자기 파괴적 행동으로 전환된 것이다. 치료자와의 관 계에서는, 치료에 늦거나 결석하는 것과 같이 강한 저항의 증거들이 보이는 면이 관찰된다. 따라서 치료자는 자해 행동 자체가 줄어드는 것에만 집중하기보다, 정신치료 과정 중에 발생하는 전이의 맥락에서 환자의 변화를 지켜보고 파악하 고 적절한 개입을 해야만 한다.

무엇보다 중요한 것 하나는 치료자가 자해란 행동에 공감 하기 어렵다는 점이다. 흔한 행동이 아니라 치료자가 직접 
경험해 보기 어려우며, 자기가 돌보는 환자의 자해는 치료자 의 놀람, 분노, 배신감, 위험신호, 공포 등 여러 가지 부정적 감정을 유발한다. 더욱이 치료자가 의사인 경우, 자해는 생 명을 위협하는 행위로서 응급결정을 할 시급함을 느끼게 만 든다. 그 결과 치료자는 가족이나 응급실에 연락하며, 치료 를 잠정적으로 중단하는 등 치료 세팅에 중대한 변화를 줄 수 있다. 그리고 치료자는 환자의 자해로 인해 배신감이나 무력감을 느낄 수도 있다. 자해를 한다는 것은 환자가 자신 의 몸을 그 무엇보다 중요한 대상(object)으로 삼은 것이기 때문에, 치료자는 자신과 환자 사이의 애착이나 연결이 끊어 졌다고 여긴다(Podvoll 1969). 치료자는 온전히 치료자-환 자 관계에 집중하지 못하게 되고, 공감적, 중립적 태도를 유 지하는 데 어려움을 겪기도 한다. 인식하지 못하는 상태에 부정적 역전이를 표현하여 치료 세팅에 영향을 주기도 한다. 이로 인해 치료자가 이전과 다른 태도로 바뀌어 환자의 공 격성과 정동을 받아주거나 반영하지 못하게 되면 더욱 강렬 한 좌절과 분노로 환자는 반응하게 된다. 그렇지 않아도 자 아 경계의 안정성이 희미한데 여기에 좌절을 겪게 된 환자 는 겉잡을 수 없이 혼란스러운 상태가 되어, 치료 세팅 밖에 서 더 강렬하고 잦은 자해 행위를 하게 될 가능성이 있다. 그 러므로 치료자는 환자의 자해가 반복되는 것에 대해 미리 충분히 인지하고 있거나 필요한 경우 수퍼비젼을 받아 역전 이의 요소나 치료자의 태도의 미묘한 변화를 조정해야 한다.

치료자는 환자의 경계의 불명확함으로 인해 생기는 불안 과 공포, 혼란을 충분히 이해해야 한다. 치료 과정 내내 이러 한 경계의 문제와 연관되어 자해는 증가하거나 감소한다. 혹 은 넓은 맥락에서 다른 행동으로 이어지는 것을 놓치지 않 아야 한다. 환자는 원치 않는 흡수와 통합(merger)에 대한 두려움도 있기에, 전이가 강하게 생기면 치료자에게 흡수당 해 버리는 것에 대한 두려움으로 인해 강한 부정적 전이 반 응(negative transference reaction)이 일어날 수도 있다. 치 료 외 시간에 자해나 기타 자기 파괴적 행위로 행동화하는 원인이 되고, 치료자에게는 강한 역전이의 원인이 될 수 있 다. 치료자는 이런 현상이 반복되는 것을 주목하여, 서서히 환자가 치료 과정 내에서 자아와 대상, 자아와 외부 환경 사 이의 경계를 명확히 하는 것을 돕는 것에 주력해야 한다. 치 료 과정에 있어 호전의 신호는 자해의 양적 감소가 아니라 경 계가 명확해지고 있다는 징후들로부터 확인할 수 있다. 흔히 반복적 자해를 치료자에 대한 관심 끌기나 조작하려는 시도 (manipulation)의 맥락에서 이해할 수도 있다. 그러나 치료 자는 환자와의 관계에서 신뢰와 안정성을 유지하기 위해 반 복적 자해 행동에 다층적 요인들이 작동하고 있다는 걸 인 식하는 것이 더욱 중요하다.
반복적 자해를 하는 환자의 자아는 일반적으로 모호함과 불확실성을 견디는 능력이 떨어지고, 쉽게 불안해지며, 감정 에 휩싸인다. 치료자는 그럴수록 안정적이고 확고한 치료 세 팅을 유지하고 환자가 이 안에서 안전감을 느낄 수 있도록 하 는 것이 우선되어야 한다(Allen 1995). 한편 정신증의 경계 수 준에 있는 환자를 정신치료 할 때, 일부 환자에게 있어 자해 행위는 자신이 치료자와 하나가 되는 대양감(oceanic feeling) 을 느끼려는 시도로 해석할 여지가 있다는 의견이 있다. 이는 극단적 애정 전이(erotic transference)의 일부이다. 강력하 고 이상화한 치료자와 하나가 되기 위해 자신의 자아의 경계 를 스스로 흐트러트려 일종의 정신증적 융합을 하는 것이다 (Tillman 1999).

반복적 자해가 정신치료라는 기법으로 호전되는 것이 중 요한 이유는 다음과 같다고 생각한다. 정신치료는 기본적으 로 언어를 통한 치유(talking cure)의 기법이다. 반복적 자해 를 하는 환자는 감정과 생각을 상징화(symbolize)하거나 말 로 표현하는 능력이 결여된 것이 특징이다. 그러므로 정신치 료에서 주목하고 유도해야 하는 것은 환자가 감정을 마음 안에서 경험하고, 이미지나 상징으로 그릴 수 있게 하는 것 이다. 감정이 의식화될 때 이를 잘 감지하여 명료화하고 세 밀화할 수 있어야 하고, 자해와 같은 충동적이며 자기파괴적 행동이 아닌 언어로 표현할 수 있도록 유도해 가는 것이 치 료자의 과제다. 그리고 정신치료는 그 목적을 위해서라면 가 장 좋은 치료법이라고 할 수 있다. 환자가 언어로 표현하는 데 갖는 어려움을 충분히 이해하고 인내를 갖고 기다리되, 정서적 조절의 어려움이 자해 행위로 전환되지 않도록 잘 관찰하며 서서히 감정을 인식하고 언어화하는 과정을 함께 한다. 치료자는 환자 자신이 충동적으로 반복하는 자해라는 행동 안에 숨어 있는 의미를 찾고 이해할 수 있도록 돕는다. 하지만 그 숨은 맥락을 안다는 것만으로 문제가 해결되는 것은 아니라는 것이 난관의 핵심이다. 그 이유는 이렇다.

첫째로, 자해의 상징적 의미를 알아내는 데 시간이 오래 걸린다. 그 사이에 계속해서 자해를 하고 이를 멈추기 어려 울 수 있다는 것이 현실적 어려움이다. 둘째, 시간이 지나 자 해의 의미를 알아냈다고 하더라도, 치료자가 안다고 해도, 환 자가 받아들이거나 이를 훈습해내기가 어렵기에 자해가 지 속된다는 것이다. 자기 행동의 의미에 대해 깨닫게 되더라도 문제를 극복할 만한 대처 능력이 부족하거나 실은 더 깊은 무의식에 숨어 있는 다른 의미가 있을 수도 있다.

치료자가 정신치료과정에서 만나는 어려움 중 하나는 환 자가 청소년기의 미성년자로 자해행동이 발생하고 자살 사 고가 강하거나, 자살 충동이 위험한 상태라 여겨질 때 이를 보호자에게 알릴지에 대한 문제다. DSM-5에서 비자살적 자 
해를 따로 분류하기도 했고, 자해 행동이 바로 자살로 이어 지지 않는다는 것도 충분히 알려졌지만, 아직까지도 자해는 자살의 큰 위험 인자이자 자살 전 단계로 인식된다. 보호자 에게 알려야만 한다는 필요를 느끼는 데 청소년의 경우 더 그렇다. 청소년 자해 환자들은 많은 수에서 부모와의 관계에 문제가 있는데, 이런 경우 부모에게 도움을 구하기는 더 어렵 다. 또한 청소년은 2 차 분리-개별화를 거치면서 감정적, 신체 적으로 부모로부터의 독립을 원한다. 그들은 도움을 원하면 서도 도움을 청하는 것을 싫어하는 역설적 딜레마에 빠져 있기도 하다. 부모에게 자신이 얼마나 힘든지 표현하고 싶은 마음이 있는 동시에 모든 과정에서 부모를 배제시키려고 하 는 경향도 함께 있다. 자해 행동을 알게 된 대부분의 부모들 의 반응은 부정, 놀람, 걱정, 분노 등이다. 청소년은 부모의 이러한 반응을 보며 자신이 이해받지 못했다고 느끼고, 때로 는 참견당하고 감시당하는 느낌에 부모나 치료자로부터 멀 어지거나 문제를 숨기는 부작용이 발생할 수 있다. 치료자는 이런 점들을 고려하여 자해가 처음 발생하거나 또는 악화되 었을 때, 치료자-환자 사이의 관계에 위험한 징후가 관찰되 는 등의 뚜렷한 변화가 있을 때에는 보호자에게 통보하거나 연락하는 부분에 대해 현실적 판단을 할 필요가 있다. 이전 에 자해를 한 적 있는 환자라면 치료 전에 자해와 같은 위험 한 징후가 발생했을 때 부모와 연락할 수 있다는 약속을 미 리 하는 것을 치료 계약의 하나로 맺어놓는 것도 방법이다. 사전 약속은 자해를 예방하는 효과도 있고, 구체적인 약속은 치료자가 부모에게 연락을 한다고 해도 치료자-환자 사이 의 비밀 보장을 깨트리지 않는 안전판이 된다.

\section{결 론}

저자들은 최근 증가하고 있는 반복적 자해의 정신역동적 의미에 대해서 알아보았다. 반복적 자해는 10 대 초반에서 시 작해서 20대 중반까지 가장 많이 관찰되며, 경계성 인격장애 의 경우에만 국한되지 않으며 광범위한 영역에서 다양한 정 신병리와 함께 발생한다. 자해는 직접적 자해 행위뿐 아니라 약물남용, 문신과 같은 넓은 맥락의 자기파괴적 행위로도 같 은 맥락에서 이해할 수 있는 측면이 있다. 자해를 정신역동 적으로 이해하는 데 있어서 여러 가지 이론적 배경으로 설 명이 가능하다. 고전적 정신분석에서는 공격적 욕동의 작동 과 타나토스, 자아심리학으로는 취약한 자아의 기능과 정서 조절의 실패, 대상관계이론으로는 불안정한 내적 표상에 의 한 경계의 불안정성, 발달적 측면에서는 언어화와 상징화 발 달의 실패, 2차 분리-개별화 이슈 등이 자해와 깊은 연관이 있었다. 반복적 자해를 하는 환자를 정신치료를 하는 과정에
특이한 전이-역전이 문제가 발생하며, 치료자는 무력감과 좌절감을 느끼기 쉽다. 치료 과정에 환자가 자해의 의미를 이해하고, 이와 연관된 감정을 상징화하고 언어화할 수 있도 록 도우며 치료자-환자 관계의 안정과 신뢰를 통해 안전하 고 분명한 경계를 형성하도록 하는 것이 반복적 자해를 감 소시키는 데 중요하다.

\section{Acknowledgments}

None

\section{Conflicts of Interest}

The authors have no potential conflicts of interest to disclose.

\section{Author Contributions}

Conceptualization: Jee Hyun Ha. Data curation: Sumin Hong. Formal analysis: Jee Hyun Ha. Funding acquisition: Jee Hyun Ha. Investigation: Jee Hyun Ha. Methodology: Jee Hyun Ha. Project administration: Jee Hyun Ha. Resources: Sumin Hong. Software: Sumin Hong. Supervision: Jee Hyun Ha. Validation: Jee Hyun Ha. Visualization: Jee Hyun Ha. Writing — original draft: Sumin Hong. Writing — review \& editing: Jee Hyun Ha.

\section{ORCID iDs}

Jee Hyun Ha https://orcid.org/0000-0002-0973-1139

Sumin Hong https://orcid.org/0000-0002-6109-6902

\section{REFERENCES}

Allen C. Helping with deliberate self-harm: some practical guidelines. J Ment Health 1995;4:243-250.

Asch SS. The analytic concepts of masochism: A reevaluation. In: Glick RA, Meyers DI. Masochism: current psychoanalytic perspectives. Hillsdale, NJ: Analytic Press;1988. p.93-115.

Conterio K, Lader W, Bloom JK. Bodily harm: the breakthrough healing program for self-injurers. New York, NY: Hyperion;1998.

Doctors SR. The symptom of delicate self-cutting in adolescent females: a developmental view. Adolesc Paychiatry 1981;9:443-460.

Driessen E, Van HL, Don FJ, Peen J, Kool S, Westra D, et al. The efficacy of cognitive-behavioral therapy and psychodynamic therapy in the outpatient treatment of major depression: a randomized clinical trial. Am J Psychiatry 2013;170:1041-1050.

Favazza AR, Rosenthal RJ. Varieties of pathological self-mutilation. Behav Neurol 1990;3:77-85.

Firestone RW, Seiden RH. Suicide and the continuum of self-destructive behavior. J Am Coll Health 1990;38:207-213.

Fonagy P. The effectiveness of psychodynamic psychotherapies: an update. World Psychiatry 2015;14:137-150.

Fowler JC, Hilsenroth MJ. Some reflections on self-mutilation. Psychoanalytic Review 1999;86:721-731.

Gyeonggi Office of Education. Screening test for students' emotional and behavioral problems 2018 [updated 2018 Aug 31; cited $2020 \mathrm{Jul}$ 30]. Available from: http://www.goe.go.kr/home/bbs/bbsDetail.do?m enuId $=100000000000262 \&$ bbsMasterId=BBSMSTR_00000000024 $6 \&$ menuInit $=12,1,1,0,0 \&$ bbsId $=972258$.

Hankyoreh. 중고생 7만여명 “자해 경험”...우리 아이는 상관없다고 요? [More than 70,000 teenagers experienced self-harm] [updated 2018 Nov 11; cited 2020 Jul 30]. Available from: http://www.hani. co.kr/arti/society/society_general/869668.html.

Himber J. Blood rituals: self-cutting in female psychiatric inpatients. Psychotherapy: Theory, Research, Practice, Training 1994;31:620-631. 
Kaess M, Parzer P, Mattern M, Plener PL, Bifulco A, Resch F, et al. Adverse childhood experiences and their impact on frequency, severity, and the individual function of nonsuicidal self-injury in youth. Psychiatry Res 2013;206:265-272.

Kernberg OF. Severe personality disorders: psychotherapeutic strategies. New Haven, CT: Yale University Press; 1984.

Klein M. The psycho-analysis of children. London: Hogarth Press;1932.

Kohut H. The analysis of the self. Madison, CT: International Universities Press; 1971.

Korea Suicide Prevention Center. 2018 Statistical data. Seoul: Korea Suicide Prevention Center;2020.

Kwon S. Study on the effect of actions using Facebook to imitative behavior and attention through negative emotions [dissertation]. Seoul: The Graduate School Ewha Womans University;2016.

Lee DG, Ham KA, Bae BH. Adolescents" self-injurious behaviors: suicidal self-injury and non-suicidal self-injury in female middle school students. Korean J Counsel Psychotherapy 2016;28:1171.

Leibenluft E, Gardner DL, Cowdry RW. Special feature the inner experience of the borderline self-mutilator. J Pers Disord 1987;1:317-324.

Lloyd-Richardson EE, Perrine N, Dierker L, Kelley ML. Characteristics and functions of non-suicidal self-injury in a community sample of adolescents. Psychol Med 2007;37:1183-1192.

Moran P, Coffey C, Romaniuk H, Olsson C, Borschmann R, Carlin JB, et al. The natural history of self-harm from adolescence to young adulthood: a population-based cohort study. Lancet 2012;379:236243.

Ministry of Health and Welfare. 자살유해정보 차단, 생명존중으로의 또 한걸음 [Blocking harmful suicide information: another step toward respect for life] [updated 2018 Aug 24; cited 2020 Jul 30]. Available from: http://www.mohw.go.kr/react/al/sal0301vw.jsp?PAR MENU ID=04\&MENU ID=0403\&CONT SEQ=345783\&page=1.

National Emergency Medical Center; Ministry of Health and Welfare; National Medical Center. Statistical yearbook of emergency medical service 2016. Seoul: National Emergency Medical Center;2017.

Noshpitz JD. Self-destructiveness in adolescence. Am J Psychother 1994; 48:330-346.
Podvoll EM. Self-mutilation within a hospital setting: a study of identity and social compliance. Br J Med Psychol 1969;42:213-221.

Raine WJ. Self mutilation. J Adolesc 1982;5:1-13.

Rao R. Wounding to heal: the role of the body in self-cutting. Qual Res Psychol 2006;3:45-58.

Ross S, Heath N. A study of the frequency of self-mutilation in a community sample of adolescents. J Youth Adolesc 2002;31:67-77.

Sarnoff CA. Adolescent masochism. In: Glick RA, Meyers DI. Masochism: current psychoanalytic perspectives. Hillsdale, NJ: Analytic Press;1988. p.205-224.

Shedler J. The efficacy of psychodynamic psychotherapy. Am Psychol 2010;65:98-109.

Simpson MA. Self-mutilation as indirect self-destructive behavior: "Nothing to get so cut up about...". In: Farberow NL. The many faces of suicide: indirect self-destructive behavior. New York, NY: McGraw Hill;1980. p.257-283.

Stolorow RD, Lachamann FM. Psychoanalysis of developmental arrests: theory and treatment. New York, NY: International University Press; 1980

Suyemoto KL. The functions of self-mutilation. Clin Psychol Rev 1998; 18:531-554.

Swannell SV, Martin GE, Page A, Hasking P, St John NJ. Prevalence of nonsuicidal self-injury in nonclinical samples: systematic review, meta-analysis and meta-regression. Suicide Life Threat Behav 2014; 44:273-303.

Tillman JG. Erotized transference and self-mutilation. Psychoanal Rev 1999;86:709-719.

Wilkinson P. Non-suicidal self-injury. Eur Child Adolesc Psychiatry 2013;22:75-79.

Winnicott DW. Primitive emotional development. In: Winnicott D. Collected papers, through paediatrics to psychoanalysis. London: Tavistock Publications;1945. p.145-156.

Yakeley J. Psychodynamic psychotherapy: developing the evidence base. Adv Psychiatr Treat 2014;20:269-279.

Zila LM, Kiselica MS. Understanding and counseling self-mutilation in female adolescents and young adults. J Couns Dev 2001;79:46-52. 